\title{
AJARAN KARMAPHALA DAN PANCA SATYA \\ DALAM GEGURITAN JAYAPRANA
}

\author{
I Wayan Dauh \\ Fakultas Ilmu Agama, Seni dan Budaya \\ Universitas Hindu Indonesia \\ Denpasar
}

\begin{abstract}
ABSTRAK
Karya sastra Bali tradisional seperti Gaguritan sangat penting perannya. Apalagi di dalamnya terdapat nilai dasar ajaran agama Hindu. Artikel ini berupaya mengkaji ajaran agama Hindu yang terkandung dalam Geguritan Jayaprana. Setidaknya, berdasarkan hasil kajian, ajaran agama Hindu yang terkandung dalam Gaguritan Jayaprana adalah (1) ajaran Karmaphala dan (2) Ajaran Panca Satya.

Kata Kunci: Ajaran Agama Hindu, Geguritan Jayaprana

ABSTRACT

Traditional Balinese literary works such as Gaguritan are very important. Especially in it there are basic values of the teachings of Hinduism. This article seeks to examine the teachings of Hinduism contained in Geguritan Jayaprana. At least, based on the results of the study, the teachings of Hinduism contained in Gaguritan Jayaprana are (1) the Karmaphala teachings and (2) the Panca Satya teachings.
\end{abstract}

Keywords: Teachings of Hinduism, Geguritan Jayaprana

\section{PENDAHULUAN}

Karya sastra Bali tradisional, yang merupakan warisan leluhur kita mempunyai khazanah nilai yang tinggi dan luhur. Begitu juga dalam meningkatkan srada masyarakat Hindu di Bali, agama sebagai iner powernya menyebabkan karya sastra itu sebagai budaya yang dinamis untuk dicintai dan dihayati sebagai tuntunan hidup oleh masyarakat pendukungnya.

Manusia yang kurang menghyati ajaran sastra, dia sering lupa pada keadaan yang sebenarnya, adalah untuk memperoleh tujuan tertinggi yaitu Sunyata, tanpa awal dan akhir, dan berada dimana-mana di alam semesta ini, adalah local dan Maha suksuma (Mantra, 2002 : 4). Di dalam kesustraan Bali Purwa yaitu tembang Bali meliputi : (1) Sekar Rare (Gending rare) , (2) Sekar Alit (3) Sekar Madya, dan (4) Sekar Agung. Salah satu dari tembang Bali yaitu Sekar Alit merupakan gending (lagu) yang sangat popular. Selain digunakan sebagai alat komunikasi atau ekspresi, juga untuk membentuk suatu Gaguritan (karya sastra yang berwujud cerita serta berbentuk puisi) misalnya, Pupuh Mijil, Pupuh 
Pucung, Pupuh Kumambang, Pupuh Ginada, Pupuh Ginanti, Pupuh Semaradana, Pupuh Sinom, Pupuh Durma, Pupuh Pangkur, dan Pupuh Dandang Gula. Di dalam Sekar Alit ini terdapat hukum-hukum Sekar Alit yaitu: (1) Padalingsa dimana Padalingsa ini merupakan jumlah baris (kalimat) pada suatu pupuh di dalam satu pada (bait), (2) Guru Wilang merupakan jumlah wanda (suku kata) di dalam satu baris (kalimat), (3) Guru ding-dong merupakan banyaknya suara vocal dalam satu baris, dan (4) Guru Gatra merupakan banyaknya baris dalam satu bait.

Salah satu dari karya sastra tersebut adalah gaguritan. Gaguritan merupakan salah satu hasil karya sastra Bali klasik, yang sampai saat ini hidup dan berkembang dimasyarakat pencintanya. Sebagai salah satu hasil karya sastra Bali kalsik, Gaguritan disajikan dengan menggunakan pupuh, dan terikat oleh aturan padalingsa. Aturan padalingsa melipui jumlah baris (carik) dalm tiap-tiap bait (pada), jumlah suku kata (kecap) dalam tiap-tiap baris dan bunyi akhir vocal tiap-tiap baris (Agastia, $1990: 70)$.

Aktualisasi dari karya sastra ini biasanya dilakukan dengan istilah mabebasan hingga masyarakat umum juga bisa memahami bentuk, fungsi, dan makna karya sastra ini. Dengan demikian masyarakat umum yang tidak bisa berbahasa jawa kuno/jawa tengah lewat mabebasan yang banyak orang ikut tersucikan hingga konsep Tri Kaya Parisudha dengan baik.

Jika proses mabebasan bisa berjalan dengan baik maka nila-nilainya yang sudah difilterisasi dapat dipakai pedoman sehari-hari sebagai senjata, untuk mengantisipasi budaya luar dalam kenyataan hidup yang multi dimensi terhadap sesuatu yang bersifat niscaya dan rekayasa. Kedua pola pengaruh sosial budaya itu kemudian pada suatu saat tertentu dapat terjadi seolah-olah dengan sendirinya tanpa diantisipasi oleh masyarakat sebelumnya. "Perubahan lain yang memang kita usahakan supaya terjadi kita namakan perubahan rekayasa" (Soermardjan, 1990 : 3, Agastia (1980 : 21) mengatakan bahwa bahasa dan sastra suatu bangsa adalah merupakan rekaman pengalaman dan hidup rohani bangsa itu maka bahasa dan sastra tidak hanya untuk memanusiakan melainkan juga untuk menyerap dan menggali sifat-sifat kepribadian bangsa.

Manusia yang hidupnya selalu berada pada yang dijiwai agama hidupnya akan selalu damai, karena secara teoritis tipe manusia yang taat akan selalu damai, karena secara teoritis yang taat beragama apapun agama yang dianutnya selalu perduli kepada persoalan kemanusiaan. Sebab persoalan itu merupakan usi universal yang menjadi bagian pelaksanaan ajaran agama-agama. (Ab.A'la 2002 : 5). Jadi aktualisasinya sastra betul-betul sebagai pegangan hidup menuju yang humanisme.

Dalam Kekawin Niratha Prakertha dikatakan Dhang Hyang Niratha menjadikan kekawin ini sebagai "Tongkat" perjalanan spiritual beliau (Agastia, 2000 : 4). Ajaran agama yang telah melekat dalam bentuk sastra ini merupakan aliran dan Veda. Veda adalah pengetahuan suci, kebijaksanaan, suci yang terutama terkandung dalam kumpulan teks yang merupakan wahyu, kumpulan pertama disebut Sruti, yang merupakan aktivitas pertama dalam hal-hal religious, mengandung kebenaran ilahi yang sudah didenger atau sejak jaman dahulu, baik secara lisan maupun tulisan, serta diturunkan dari generasi ke generasi (Mariasuasi, 1995 : 90). 
Karya seni berupa Gaguritan banyak digunakan oleh para seniman dalam menuangkan ide-ide cemerlang berupa membahas ajaran agama Hindu dengan bahasa seni yang lebih mudah dicerna oleh masyarakat awam dan bagi mereka yang memiliki kelebihan seni matembang. Pada umumnya karya seni Gaguritan mengandung ajaran-ajaran agama Hindu berupa petuah-petuah, tutur-tutur atau ajaran etika dan budi pekerti, termasuk juga mengandung ajaran tattwa yang diambil dari salah satu ajaran agama Hindu.

Karena begitu pentingnya karya sastra Bali tradisional seperti Gaguritan maka sudah saatnya kita generasi muda untuk mengkaji dan mengapresiasi sebagai bahan penelitian baik dari segi bentuk maupun fungsinya, sehingga karya sastra itu betul-betul sebagai srada dalam memahami roda kreatifitas tiada henti dalam menghadapi persaingan global. Dewasa ini tak lepas dari tujuan akhir sebagai manusia untuk bisa sampai pada yang satu itu. Adapun beberapa contoh Gaguritan yang ada di Bali yaitu: Gaguritan Tamtam, Gaguritan Cupak Grantang, Gaguritan Pakang Laras, Gaguritan Jayaprana, dan lai-lain. Salah satu Gaguritan yang menarik adalah Gaguritan Jayaprana. Penulis tertarik dengan Gaguritan Jayaprana karena (1) mengandung banyak nilai-nilai pendidikan, (2) Bahasanya mudah dicerna atau mudah dimengerti, (3) ceritanya sangat menarik atau komplek, (4) Didalamnya terdapat banyak pesan-pesan moral, dan (5) suasana dan isi cerita lebih kompleks. Gaguritan ini menceritakan tentang kisah percintaan Jayaprana dan Layonsari.

Penulis ingin meneliti lebih dalam tentang makna ajaran agama Hindu yang terkandung didalamnya. Lebih dari itu yang melatarbelakangi penulis meneliti Gaguritan Jayaprana adalah ingin mengetaui bagaimana struktur, ajaran agama Hindu dan nilai-nilai pendidikan agama Hindu yang terkandung didalamnya. Kesemua hal inilah yang melatar belakangi penulis meneliti Gaguritan Jayaprana khususnya yang berkaitan dengan ajaran agama Hindu.

\section{PEMBAHASAN}

\subsection{Ajaran Agama Hindu yang Terkandung dalam Gaguritan Jayaprana \\ a. Ajaran Karmaphala}

Secara leksikal kata karmaphala berasal dari kata karma yang artinya perbuatan dan phala atinya buah, biji, hasil, akibat, upah, ganjaran (Astra, 2000 : 129 \&162). I Made Rintia (1981 : 8) mengatakan karmaphala memiliki arti hasil dari perbuatan yang terdiri dari Sancita Karmaphala, Prarabda Karmaphala, dan Kriyamana Karmaphala. Sancita Karmaphala adalah bagian hukum karmaphala yang pertama yang memiliki arti phala yang terdahulu yang belum habis dinikmati dan menjadi benih yang menentukan keadaan kehidupan sekarang. Manusia (dan semua makhluk hidup) lahir ke dunia dengan membawa phala dari karma yang lampau. Agama Hindu meyakini bahwa sebelum makhluk hidup menjelma pada kehidupan sekarang, mereka pernah mengalami keidupan pada masa lalu. Akan tetapi, seringkali manusia tidak mengetahui kehidupannya pada masa lalu. Hal ini sebagaimana dijelaskan dalam Bhagawadgita, IV.5, sebagai berikut :

Bahuni vyantitani, janmani tava'rjuna, 
Tanyaham veda sarvani, na tvam vttha paramtapa.

Artinya :

Banyak kehidupan yang aku telah jalani, demikian juga engkau,O Arjuna.

Semua kelahiran itu aku ketahui, tetapi engkau tidak mengetahui O Arjuna (Mantra, 2009 : 61).

Sesungguhnya manusia telah mengalami kelahiran dan kematian berulangulang, tetapi tidak menyadarinya. Hal ini karena Sang Atma yang dibungkus oleh sukma sarira (badan astral) tidak menyadari dirinya sendiri. Pada akhirnya, perbuatan-perbuatan yang dilakukan akan melekat pada sukma sarira (badan astral). Ketika jasad meninggal, sukma sarira meninggalkan badan lama dan masuk ke badan baru dengan membawa karma yang dilakukan selama hidupnya (Gunadha, 2013 :128).

Prarabda Karmaphala adalah karma yang dilakukan pada kehidupan sekarang dan pahalanya juga habis dinikmati sekarang. Secara jesmani, hukum ini mudah diamati pada tindakan manusia sehari-hari, misalnya seorang makan akibatnya kenyang atau seorang yang mengantuk akan hilang kantuknya setalah tidur pulas. Seorang pencuri yang tertangkap kemudian dihajar masa dan akhirnya dipenjara, juga menunjukan karma yang langsung dinikmati phalanya (Gunadha, $2013: 130)$.

Demikianlah, atas segala perbuatan (karma), seseorang pasti akan menerima hasilnya cepat atau lambat. Padahal manusia tidak dapat menghindari kerja dalam hidupnya, sebagaimana dijelaskan dalam Bhagawadgita, III.8, sebagai berikut :

Niyatam kuru karmatvam, karma jyano hyakarmanah,

Sarira yatrapi ca ten a prasidhyet akarmanah. Artinya :

Lakukan tugas dan kewajiban yang telah ditetapkan kepadamu, sebab bekerja lebih baik daripada tidak bekerja. Bahkan, engkau tidak kaan bisa memelihara badan jesmanimu tanpa bekerja.

Setiap manusia harus melaksanakan kerja sesuai yang telah ditetapkan sesuai tugas dan kewajibannya. Manusia yang menghindari tindakan kerja, bahkan sama dengan mengingkari eksistensinya sendiri. Kerja diperlukan untuk mempertahankan eksitensi manusia du dunia ini, misalnya orang bekerja untuk mencari makan karena makanan diperlukan oleh tubuh.

Manusia harus melaksanakan kerja yang dapat dinikmati hasilnya pda saat ini terutama demi keberlangsungan hidupya. Inilah yang disebut dengan Karma Sanggga. Karma Sangga adalah segala perbuatan (karma) dalam tugas dan kewajiban yang berhubungan dengan kehidupan duniawi dan kehidupan sosial. Karma Sanggga dapat dibedakan menjadi dua, yaitu karma kara apabila manusia bekerja dengan tenaga jasmaninya dan menerima upah, dan karma ksama apabila seseorang bekerja dnegan tenaga rohaninya dan menerima upah. Pada dasrnya, upah ini adalah phala yang langsung dinikmati dalam kehidupan sekarang.

Meskipun demikian, penting dipahami bahwa karmaphala tidak menentukan nasib manusia saat kehidupan sekarang. Akan tetapi, juga karma 
yang dilakukan pada kehidupan sekarang akan menentukan kehidupan pada kelahiran berikutnya (punarbhawa). Oleh karena itu, manusia tidak dibenarkan bekerjanya hanya untuk sekedar menerima upah, apabila berfikir hedonis bahwa bekerja hanya untuk memenuhi nafsu selera. Apabila Hindu merumuskan tujuan kehidupan adalah mencapai artha, kama, dan moksa, maka tujuan tersebut harus dicapai dengan kerja berdasarkan dharma. Dengan demikian , kerja menjadi tindakan yang bermanfaat bagi kebaikan masa kini dan kebaikan pada masa depan (Gunadha, 2013 : 132).

Kriyamana Karmaphala, yaitu perbuatan yang hasilnya belum sempat dinikmati pada masa sekarang, tetapi akan dinikmati pada kehidupan berikutnya (Gunadha $2013: 133$ ).

Sebagai salah satu contoh bentuk karmaphala dalam Gaguritan Jayaprana, bisa dilihat pada usaha Raja Kalianget yang ingin memperdaya dan membunuh I Jayaprana untuk memperistri Ni Layonsari akan tetapi Ni Layonsari yang tidak mau menikah dengan Raja akhirnya membunuh dirinya sendiri. Raja yang mengetahui hal itu akhirnya marah dan mengakhiri hidupnya . Peristiwa ini dapat dilihat pada Pupuh Ginada bait 75, 76, 166, dan 171 ,yaitu :

Anake Agung ngandika, teken prebekele sami, kenken ban maman ngraos, edengin jua kuda aku, merentah I Jayaprana, panga mati, gawenang daya-upaya.

Mangde yennya suba pejah, I Nyoman apanga manjing, yan kai tuara mabaan, Nyai Nyoman Dewa Ratu, tan urungan kai pejah, mati sedih, yan tan polih Nyai Nyoman.

Saup sangkol aras-aras, bangkene jua papasihin, nyai Nyoman Dewan titiang, munyine patijelamut, tuara karoan jejalangan, dadi paling, panyingakan kasaputan. 
Tuara karoan musuh roang,

sing paak pada tebekin,

getihe nyandang kerobok,

bangkene tan kena itung,

Anake Agung ia pejah,

ne ne mangkin,

sedane manyuduk raga.

Selain ajaran Karmaphala sebagaimana konsentrasi penelitian juga ada ajaran lain misalnya ajaran keharmonisan, reinkarnasi, dan kesejahteraan hidup diajarkan pula pada Gaguritan Jayaprana ini.

\section{Ajaran Panca Satya}

Satya adalah merupakan unsur keimanan yang pertama dalam agama Hindu menurut kitab suci Atharva Veda XII.1.1. Kata "satya" berasal dari bahasa Sansekerta, dari urat kata "Sat" yang berarti Kebenaran, kejujuran, Tuhan (ketuhanan). Dengan demikian kata Satya mengandung arti sebagai berikut :

1) Satya berarti kebenaran yaitu merupakan sifat hakikat dari Tuhan Yang Maha Esa, maka kata itu diartikan sama dengan kata "dewa" yaitu aspek sifat Tuhan atau wujud kekuasaan Tuhan yang bersifat khusus (atau sama dengan Malaikat).

2) Satya berarti kesetiaan atau kejujuran Kata ini biasanya dirangkaikan dengan kata "Wak" atau "Wac" yang berarti kata-kata, ucapan. Misalnya Satya Wacana berarti setia pada kata-kata atau ucapan, maka segala apa yang dikatakan akan dilakukan sesuai menurut janji itu. Dari sinilah kemudian berkembang ajaran Panca Satya yaitu Lima macam kesetiaan.

Dalam ajaran agama Hindu Satya terdiri dari lima, oleh sebab itu dinamakan Panca Satya. Adapun bagian-bagiannya adalah sebagai berikut :

1) Satya Wacana, adalah setia, jujur dan benar dalam berkata-kata. Tidak mengucapkan kata-kata yang tidak sopan yang disebut "wak purusya".

2) Satya Hredaya, adalah setia terhadap kebenaran dan kejujuran kata hati, berpendirian teguh, dan tidak terombang-ambing .

3) Satya Laksana, adalah sikap setia dan jujur mengakui serta mempertanggungjawabkan kebenaran dari segala perbuatan yang telah dilakukan.

4) Satya Mitra, adalah setia dan jujur kepada teman dalam segala hal, serta berusaha untuk mengarahkan segala tindakan atau perbuatan agar selalu berdasarkan kebenaran sesuai dengan ajaran agama.

5) Satya Samaya, adalah setia dan jujur terhadap janji yang telah diucapkan serta memenuhi segala sesuatu yang ditimbulkan akibat ucapan janji itu. 
Kalimat satya itu hendaknya dapat diwujudkan dalam pelaksanaan tindakan dan perbuatan dalam kehidupan sehari-hari. Berusaha jangan berbohong kepada diri sendiri maupun orang lain. Sebab hal ini dapat mengakibatkan pikiran gelisah karena merasa bersalah. Terdapat beeberapa referensi yang berkaitan dengan ajaran Satya, yaitu :

1) Dalam Sarasamuccaya Sloka 130 dikatakan :

Yan ring janma manusa, brahmana sira lwih kunang yan ring teja,

sang bhyang aditya sira lwih, yan ring awayawa,

nang panipadadi, hulu ikang wisesa,

yapwan ring dharma, nghing kasatyan wisesa

Artinya :

Maka diantara yang lahir sebagai manusia brahmanalah yang utama; diantara yang bersinar, matahari itulah yang utama; mengenai anggota tubuh, seperti tangan, kaki dan lain-lain kepalalah yang utama; jika mengenai dharma, maka satya (kebenaran) yang mengatasi keseluruhannya.

Apabila kita cermati dari sloka tersebut, maka begitu pentingnya sebuah ajaran kesetiaan, kejujuran dan kebenaran (satya). Satya merupakan hal yang paling hakiki yang harus tetap diterapkan di jaman kali yuga atau jaman kemajuan dunia teknologi dan komunikasi ini. Jika manusia atau umat dapat menjabarkan dan mengaplikasikan semua ajaran satya (kebenaran) ini akan terciptalah suasana aman. Brahmana mempunyai tugas yang cukup mulia tetapi semua harus disadari bahwa, manusia itu merupakan mahluk yang memiliki kemampuan untuk berpikir, memilah dan memilih sesuatu dengan akal sehat kepribadiannya.

2) Dalam Sarasamuccaya Sloka 131 dikatakan :

Hana tang wang ujar makaphala laraning para, umakusara siddha ning karyaning kunang, ndan mithya ya,

ikang wwang mangkana kramanya, tan atakut ring naraka ika,

ta karin pagawayaken awaknya kapapan ngaranika,

apan ikang para prasiddhaning mukti kapapanya,

sangksepanika, tan ujarakenang ujar mangkana

Artinya :

Adalah orang yang berkata, yang mengakibatkan kesedihan orang lain, entahlah menyanggupi atas selesainya kerja orang lain, akan tetapi ternyata ia berbohong; orang yang demikian perilakunya tidak takut akan kawah neraka; bukanlah ia berbuat celaka bagi dirinya sendiri, sekalipun orang lain sebenarnya yang mengalami malapetaka itu; singkatnya, janganlah mengucapkan perkataan yang demikian itu

Melaksanakan suatu pekerjaan yang dengan hanya mengutamakan ego diri sendiri akan menyebabkan suatu permasalahan. Masalah akan muncul bila seorang pemimpin atau orang yang diutamakan dalam suatu struktur pekerjaan akan menciptakan suasana yang kurang harmonis. Mengucapkan perkataan dalam memberikan suatu tugas kepada orang lain hendaknya dengan menggunakan tutur kata dan bahasa yang sopan. Seandainya seorang yang mengungkapkan atau menyampaikan suatu pernyataan dengan tutur bahasa yang kasar, ini dapat 
menyebabkan rasa tersinggung dan niatan-niatan yang tidak dapat dikendalikan. Setidaknya, dalam mengungkapkan suatu perkataan harus dilandasi dengan halhal yang telah disebutkan diatas.

Berpikir, berkata serta berbuat yang baik merupakan cerminan yang telah diajarkan dalam ajaran agama Hindu yaitu Tri Kaya Parisudha (Kayika, wacika dan manacika). Setidaknya manusia harus melandasi diri dengan ajaran yang telah diajarkan oleh ajaran Tri Kaya Parisudha. Singkatnya setiap manusia harus mengetahui bagaimana mengetahui keadaan dan situasi yang sedang dihadapi dan tengah berlangsung. Menjaga tutur bahasa harus benar-benar dijaga untuk mengatasi terjadinya kesalahpahaman dan masalah.

3) Dalam Sarasamuccaya sloka 132 dikatakan:

Kuneng lwir ingujarakena nihan, satya ta ya

makawak hingsa, haywa makawak upet,

hitawasana ta ya, haywa ta parusya,

haywa kasletan gleng, haywa pesunya

mangkana twirning tan yogya ujarakena.

Artinya :

Adapun kata-kata yang patut diucapkan, ialah kata-kata yang mengandung kebenaran; jangan yang berupa penusuk hati, jangan yang merupakan umpatan, hendaklah kata-kata yang bermanfaat, janganlah kata-kata yang kasar, jangan kata-kata yang terpengaruhi kemarahan, jangan kata-kata mementingkan diri sendiri, jangan kata-kata fitnahan; demikianlah misalnya kata-kata yang tidak dikeluarkan.

Menjadi seorang pemimpin hendaknya menjaga setiap tutur kata dan bahasa yang hendak dilontarkan. Begitu juga setiap manusia dalam melakukan komunikasi antar sesama, hendaknya tetap menjaga norma kesopanan dan kebenaran dalam mengeluarkan perkataan. Didalam pergaulan umat beragama semestinya harus menjaga kebenaran dalam menyampaikan ajaran agama dan bisa menjadi panutan bagi umat-umat yang lain.

Menghindari pengucapan kata-kata yang dapat menyinggung perasaan orang lain memang tidaklah mudah. Hal ini memang benar-benar harus dilatih dan dibiasakan penerapannya. Dasar dari segala tindakan perkataan yang dapat dilontarkan oleh setiap manusia atau umat beragama hendaknya dilandasi atas dasar ajaran agama. Menghentikan pemikiran yang kotor setidaknya mampu mengurangi sikap dalam melontarkan tutur bahasa yang dapat menyakitkan.

Mengeluarkan umpatan kepada orang lain harusnya tidak dilakukan. Ini dapat menyebabkan timbulnya masalah-masalah yang mungkin tidak diinginkan oleh setiap orang. Seseorang yang telah melatih diri atau membiasakan segala tindakannya itu atas dasar kebenaran, akan memudahkan dirinya untuk mencapai satya (kebenaran) yang sejati.

4) Dalam Sarasamuccaya sloka 133 yang berbunyi :

Nihan laksananing satya, hana ya tinanan tatan pawuni, majar ta ya, yatbabhuta, torasi ikang sakawruhnya, prawrttinya ikang mangkana, 
yatika laksananing kasatyan.

Artinya :

Ciri orang yang cinta kebenaran, (adalah demikian) jika ada sesuatu yang ditanyakan sekali-kali ia tidak menyembunyikannya, tetapi diberitahukan olehnya menurut kejadian yang sebenarnya, dan secara jujur segala yang diketahuinya; yang demikian, itulah perilaku setia kepada kebenaran.

Sesunguhnya orang-orang yang telah melaksanakan kebenaran dalam hidupnya telah mengartikan tuhan yang berstana dalam diri orang tersebut. Karena sesungguhnya orang yang cinta terhadap kebenaran adalah orang-orang yang jauh dari kehidupan yang nista.

Manusia adalah mahluk berpikir yang dapat menerjemahkan segala keinginan manusia yang lainnya. Kebenaran yang didasarkan atas dasar cintakasih dan kesetiaan akan teraplikasikan dalam kehidupan dan realita yang ada. Dengan saling menyeimbangkan keadaan disekitar, hal ini akan mampu menciptakan kesejahteraan diantara manusia dan mahluk ciptaan tuhan yang lainnya.

5) Dalam Sarasamuccaya sloka 135 yang bunyinya :

Matangnyan prihen tikang bhutahita, haywa tan masih ring sarwaprani, apan ikang prana ngaranya, ya ika nimittaning kapagehang ikang caturwarga, nang dharma, artha, kama, moksa, hana pwa mangilangaken prana, ndya ta tan hilang de nika, mangkana ikang rumaksa ring bhutahita, ya ta mamagehaken caturwarga ngaranya,

abhutahita ngaranikang tan karaksa denya.

\section{Artinya :}

Oleh karenanya usahakanlah kesejahteraan mahluk itu jangan tidak menaruh belas kasihan kepada segala mahluk, karena kehidupan mereka itu menyebabkan tetap terjamin tegaknya caturwarga, yaitu dharma, artha, kama dan moksa; jika mau mencabut nyawanya mahluk, betapa itu tidak musnah olehnya; demikianlah orang yang menjaga kesejahteraan mahluk itu, ia itulah yang disebut menegakkan caturwarga; dinamakan abhutahita, jika sesuatunya itu tidak terjaga atau terlindungi olehnya.

Melaksanakan kebenaran tanpa memberikan belas kasihan kepada orang lain atau mahluk lain. Merupakan suatu tindakkan yang kurang dapat menyelaraskan keseimbangan antara manusia dan mahluk ciptaan tuhan lainnya. Kehidupan dan satya (kebenaran) ialah suatu yang wajib dan mesti dilaksanakan oleh setiap manusia. Dalam caturwarga disebutkan bahwa tujuan dari hidup adalah dharma, artha, kama dan moksa. Yang semuanya itu dapat diwujudkan dengan adanya hubungan yang serasi antara sesama manusia dan mahluk ciptaan tuhan lainnya.

Manusia jika tidak mempunyai kebaikan, kebajikan, tidak menghiraukan kesejahteraan mahluk (abhutahita), akan menurunkan kualitas dari manusia itu sendiri dihadapan tuhan. Haruslah manusia dapat mensejahterakan diri sendiri, 
orang lain dan mahluk ciptaan tuhan lainnya dengan menegakkan satya (kebenaran).

6) Dalam Lontar Nitisastra (Sargah V.3 Kusumawicitra) disebutkan sebagai berikut :

Wasita nimittanta manemu Laksmi.

wasita nimittanta pati kepangguh.

Wasita nimittanta manemu Dukha.

Wasita nimittante manemu mitra.

Artinya:

Oleh perkataan anda akan mendapat Bahagia. Oleh perkataan anda akan mendapat Kematian. Oleh perkataan anda akan mendapat Kesusahan. Oleh perkataan anda akan mendapat Sahabat.

Di dalam Gaguritan Jayaprana terdapat beberapa Pupuh Ginada yang termasuk di dalam Panca Satya, antara lain :

1. Satya Wacana, terdapat dalam Pupuh Ginada bait 149 dan 177 yaitu :

\author{
I Layonsari belbelan, \\ manyumbah raris mangeling, \\ pesu munyine nyalesos, \\ titiang pamit ring I Ratu, \\ titiang tumut pramasatia, \\ ne ne mangkin, \\ Anake Agung ngandika.
}

\title{
I Jayaprana angucap, rauh saja dewa Gusti, makelo titiang mangantos, I Layonsari sumaur, titiang eling ring sengketa, bareng mati, ala ayu bareng titiang.
}

2. Satya Hredaya, terdapat dalam Pupuh Ginada bait 111 dan 116
Sampun tatas ya pinaca, salinging surate sami, Jayaprana lingnialon, titiang ngiring Dewa Ratu, titiang suka kapademang, tan pasisip, lamun ento masin titiang. 
Tuara titiang takut pejah, mangiring kayun I Gusti, sadiane mamula titiang, mangkin kayun ida ngabut, prebekele kapiwelas,

pada ngeling,

ngatonang I Jayaprana.

3. Satya Laksana terdapat dalam Pupuh Ginada bait 108 dan 114
Masih Maman cai Nyoman, maman kautus ne mangkin, antuk Gustin caine reko, apang ada salah sengguh, puniki surat paica, teken cai,
I Jayaprana mananggap.
Masih Maman cai Nyoman, maman kautus ne mangkin, da cai salah raos, apan sih maman kautus, mangiringang pangandika, ia te jani, mamargi cai pang melah.

4. Satya Mitra dan Satya Semaya, terdapat dalam Pupuh Ginada bait 160 dan 163

I Layonsari angucap, titiang mapamit ne mangkin, yan kayun I Ratu ngantos, suene solas dalu,

Anake Agung semu maras, Mamaakin,

I Nyoman manganggar pedang.

Sedihe tong kena pasah, 
dadi I ngelalu pati,

tuara wedi ngunus pedang,

kasuduk luuring susu,

sapisan laut ia pejah,

embeh rawit,

layone kadi mapeta.

I Jayaprana angucap,

rauh saja dewa Gusti,

makelo titiang mangantos,

I Layonsari sumaur,

titiang eling ring sengketa,

bareng mati,

ala ayu bareng titiang.

Demikianlah ajaran Panca Satya yang terkandung di dalam Gaguritan Jayaprana, namun demikian jika didalami lebih lanjut terdapat ajaran lain yang terkandung seperti misalnya ajaran Ketuhanan (Prema) dan ajaran Keindahan (Estetika).

\section{PENUTUP}

Karya sastra Bali tradisional seperti Gaguritan sangat penting perannya. Apalagi di dalamnya terdapat nilai dasar agama Hindu. Ajaran agama Hindu yang terkandung dalam Gaguritan Jayaprana adalah (1) ajaran Karmaphala dan (2) Ajaran Panca Satya. Karmaphala dalam Gaguritan Jayaprana, bisa dilihat pada usaha Raja Kalianget yang ingin memperdaya dan membunuh I Jayaprana untuk memperistri Ni Layonsari akan tetapi Ni Layonsari yang tidak mau menikah dengan Raja akhirnya membunuh dirinya sendiri. Raja yang mengetahui hal itu akhirnya marah dan mengakhiri hidupnya.

\section{DAFTAR PUSTAKA}

Aba'la, 2002. Melampaui Dialog Agama, Jakarta : Kompas.

Agastia, Ida Bagus Gede, 1990. Gaguritan Sebuah Bentuk Karya Sastra Jawa Kuno Bali, untuk Seserahan Sastra Daerah Pesta Kesenian Bali ke-2. , 1997. Gaguritan Sebuah Bentuk Karya Sastra Jawa Kuno Bali, untuk Seserahan Sastra Daerah Pesta Kesenian Bali ke-2. , 2000. Nirartha Prakreta. Denpasar : Yayasan Dharma Sastra.

Amirin, T. 1990. Menyusun Rencana Penelitian. Jakarta : Rajawali Press. 
Arikunto, Suharsimi. 1997. Prosedur Penelitian Suatu Pendekatan Praktek. Jakarta : Rineka Cipta.

Astra, I Gede Semadi. 2000. Kamus Kecil Sansekerta Indonesia. Pemda Bali : Titib.

Badudu-Zain, 1994. Kamus Umum Bahasa Indonesia. Jakarta : Pustaka Sinar Harapan.

Bandem, I Made dan Sal Murgiyanto. 1996. Teater Daerah Indonesia. Yogyakarta : Kanisius.

Bartens, K. 1994. Etika. Jakarta : Gramedia Pustaka Utama.

Dalyono, M. 2001. Psikologi Pendidikan. Jakarta : PT. Rineka Cipta.

Djlantik. A.M. 1999. Estetika Sebuah Pengantar. Bandung : MSPI.

Eten, Mursal. 1978. Sastra Indonesia dan Tradisi Subkultur. Bandung : Angkasa.

Gaguritan Jayaprana. 1985. Pemerintah Provinsi Bali : Bali.

Ghoni, Muhamad Djunaidi. 1982. Nilai Pendidikan. Surabya : Usaha Nasional.

Ginarsa, Ketut. 1978. Gaguritan Jayaprana. Departemen Pendidikan dan Kebudayaan : Jakarta.

Gorda, IGN. 1994. Pengetian Dasar Manajemen Sumber Daya Manusia. Denpasar : Widya.

Gunadha, Ida Bagus. 2013. Panca Sradha Lima Prinsip Keimanan Hindu Indonesia, Denpasar : Widya Dharma.

Hasan, Iqbal. 2002. Pokok-pokok Materi Metodelogi Penelitian dan Aplikasinya. Jakarta : Ghalia Indonesia.

Jendral, dkk, I Made, TT. 1946. Lonta Denpasar : Dinas Kebudyaan P

Kadjeng, I Nyoman. 2005. Sarasamu

75 )aya : Paramita.

Koentjaraningrat. 1997. Metode-m€ tian Masyarakat. Edisi Ketiga. Jakarta : Grafindo.

Kaelan. 2005. Metode Penelitian Kualitatif Bidang Filsafat. Yogyakarta : Paradigma. 
Mariasuasai, Dhavamony, 1995. Fenomenologi Agama. Yogyakarta : Penerbit Knisius (Anggota IKAPI).

Mantra dkk, Ida Bagus, 2002. Ciwa-Buddha Puja di Indonesia. Denpasar : Yayasan Dharma Sastra.

Moleong, Lexy. 1993. Metodelogi Penelitian Kualitatif. Bandung : Remaja.

Mulyana, Dedy. 2004. Metodelogi Penelitian Kualitatif : Paradigma Baru Ilmu Komunikasi dan Ilmu Sosial Lainnya. Bandung : Remaja Rosdakarya.

Poerwadarminta, W.J.S. 1976. Kamus Umum Bhaa Indonesia. Jakarta : Balai Pustaka.

Poerbakawatja \& H. A. H. Harahap. 1981. Eksiklopedi Pendidikan. Jakarta : Gunung Agung.

Redana, I Wayan. 2004. Teknik Pondasi. Denpasar : Udayana University Pers.

Sedarmayanti. 2002. Metodelogi Penelitian. Jakarta : Mandar Maju.

Soemardjan, Selo, 1990. “Modernisasi Dalam Masyarakat Indonesia”. Denpasar : Sastra Universitas Udayana.

Subagyo, Pangestu. 2004. Statistik Terapan. Yogyakarta : BPFE.

Sudikan, Satya Yuwan. 1986. Penentuan Penyusunan Karya Ilmiah. Semarang : Aneka Ilmu.

Sumaryono. 1993. Hermeneutik, Sebuah Metode Filsafat. Yogyakarta : Penerbit.

Teeuw. 1984. Sastra dan Ilmu Sastra : Pengantar Teori Sastra. Jakarta : Dunia Pustaka Jaya.

The Liang Gie. 1976. Garis Besar Estetik. Yogyakarta : Karya.

Tinggen, I.N. 1982. Aneka Rupa Paribasa Bali. Tim Peneliti Universitas Udayana.

Widiana, I Made. 1989. Gaguritan Jayaprana. Unit Pelaksana Daerah (UPD) Pusat Dokumentasi Kebudayaan Bali : Provinsi Bali.

Zoetmulder, PJ. 1983. Kalangwan : Sastra Jawa kuno Selayang pandang. Jakarta : Djambatan.

Jakarta

1974. Kalangwan : Sastra Jawa kuno Selayang pandang.

Djambatan. 